\title{
Ciência jurídica e o critério de refundação epistêmico segundo a autopoiese do ôntico- humanista
}

\author{
Djovani Pozzobon ${ }^{1}$ \\ Josemar Sidinei Soares ${ }^{2}$
}

\begin{abstract}
Resumo: O presente trabalho dedica-se ao estudo da Ontopsicologia relacionada ao Direito. Portanto, o objetivo do trabalho é estudar a relação entre Ontopsicologia e Direito em base ao critério de refundação epistêmico segundo a autopoiese ôntico-humanistico, examinando as principais referências existentes sobre Direito, Ontopsicologia e autopoiese, a fim de verificar como ocorre no plano concreto a aplicação da ciência ontopsicológica nos trabalhos realizados pelos profissionais do Direito. O método utilizado foi o qualitativo. Com o transcurso dos anos, a sociedade emergiu em assuntos superficiais e deslocados do real conhecimento sobre o humano. Dessa maneira, o Direito também experimentou os resultados de ser pensado e aplicado por gerações de juristas que viveram na superficialidade humana ou que não compuseram sua vida conforme a ordem da natureza. Portanto, atualmente, existe um Direito maculado por estas gerações de pensadores e necessita ser refundado por mentes hígidas e que apliquem o conhecimento humanista na elaboração, interpretação e aplicação das leis em prol de uma sociedade mais humanizada e menos robotizada. Professor Antonio Meneghetti informa a passagem para a refundação do Direito, que é critério epistêmico segundo a autopoiese do ôntico-humanista. Portanto, a conclusão do trabalho ocorreu no sentido de que é possível refundar o Direito através da aplicação da metodologia ontopsicológica, sempre em favorecimento e evolução da sociedade.
\end{abstract}

Palavras-chave: Autopoiese; Direito; Ontopsicologia.

Ciência jurídica e o critério de refundação epistêmico segundo a autopoiese do ôntico-humanista

Abstract: The present work is dedicated to the study of Ontopsychology related to Law. Therefore, the objective of the study is to study the relationship between Ontopsychology and Law based on the criterion of epistemic refounding according to ontico-humanistic autopoiesis, examining the main references on Law, Ontopsychology and autopoiesis, in order to verify how concrete application of Ontopsychology in the work done by law professionals.

\footnotetext{
${ }^{1}$ Possui graduação em Bacharelado em Direito - Antonio Meneghetti Faculdade (2017). Especialista em Direito Empresarial pela Pontifícia Universidade Católica do Rio Grande do Sul. Advogado.

${ }^{2}$ Doutor em Filosofia pela Universidade Federal do Rio Grande do Sul (2009), Mestre em Ciência Jurídica pela Universidade do Vale do Itajaí (2003), Mestre em Educação pela Universidade Federal de Santa Maria (1999), especialista em Psicologia Social pela Universidade Estatal de São Petersburgo (Rússia). É professor dos cursos de Mestrado e Doutorado no Programa de Pós-Graduação Stricto Sensu em Ciência Jurídica da Universidade do Vale do Itajaí UNIVALI. Como docente atua principalmente na linha de pesquisa Estado, Transnacionalidade e Sustentabilidade, vinculada à área de concentração Principiologia Constitucional e Política do Direito, do Programa de Pós-Graduação em Ciência Jurídica da UNIVALI.
} 
The method used was qualitative. Over the years, society has focused in superficial and displaced subjects of real knowledge about the human. In this way, law also experienced the results of being thought and applied by generations of jurists who lived in human superficiality or who did not compose their life according to the order of nature. Therefore, at present, there is a right tarnished by these generations of thinkers and needs to be refounded by sound minds and apply humanistic knowledge in the elaboration, interpretation and application of laws in favor of a more humanized and less robotized society. Professor Antonio Meneghetti informs the passage to the refoundation of law, which is epistemic criterion according to the autopoiesis of the ontic-humanist. Therefore, the conclusion of the work occurred in the sense that it is possible to refound the law through the application of the ontopsychological methodology, always in favor and evolution of society.

Key words: Autopoiesis; Law; Ontopsychology.

\section{La ciencia jurídica y los criterios de reembolso epistémico según la autopoítis humanista ontica}

Resumen: El presente trabajo está dedicado al estudio de la Ontopsicología relacionada con el Derecho. Por lo tanto, el objetivo de este trabajo es estudiar la relación entre Ontopsicología y Derecho basada en el criterio de remodelación epistémica de acuerdo con la autopoiesis ôntico-humanista, examinando las principales referencias existentes sobre Derecho, Ontopsicología y autopoiesis, para verificar cómo ocurre en el plan concreto. Aplicación de la ciencia ontopsicológica en el trabajo realizado por profesionales del Derecho. El método utilizado fue el cualitativo. Con los años, la sociedad ha surgido en asuntos superficiales y desplazados de conocimiento real sobre lo humano. De esta manera, la Ley también experimentó los resultados de ser pensada y aplicada por generaciones de juristas que vivían de la superficialidad humana o que no componían sus vidas de acuerdo con el orden de la naturaleza. Por lo tanto, hoy existe una Ley contaminada por estas generaciones de pensadores y necesita ser refundada por mentes sanas que apliquen el conocimiento humanista en la elaboración, interpretación y aplicación de leyes a favor de una sociedad más humanizada y menos robótica. El profesor Antonio Meneghetti informa el pasaje para la refundación de la Ley, que es un criterio epistémico según la autopoiesis del ôntico-humanista. Por lo tanto, la conclusión del trabajo fue que es posible refundar la Ley mediante la aplicación de la metodología ontopsicológica, siempre a favor y evolución de la sociedad.

Palabras clave: Autopoiesis; Derecho; Ontopsicologia.

\section{Introdução}

O presente trabalho é uma contribuição para a comunidade científica que se dedica ao estudo da Ontopsicologia, do Direito e da Ontopsicologia relacionada ao Direito. Tratase de um estudo que aborda o critério de refundação epistêmico segundo a autopoiese do ôntico-humanista. 
O tema em análise é abordado, essencialmente, por Antonio Meneghetti, sendo ele, pois, o principal autor estudado no presente trabalho. Entretanto, considerando que a Ontopsicologia propõe-se como uma ciência interdisciplinar, será realizada uma conversação com outros autores que tratam assuntos correlatos ao tema e que enriqueçam o presente trabalho.

Acerca da autopoiese, ponto nevrálgico do trabalho, a conversação entre autores ocorrerá, inicialmente, com Humberto Maturana e Francisco Varela, que atribuíram ao termo "autopoiese" o sentido de sistema vivo e seus elementos constitutivos, partindo de premissas biológicas e filosóficas relacionados à indagação de como se pode definir um ser vivo. Realizar-se-á um diálogo entre os autores para compor a temática em uma visão circular do que se entende pela autopoiese e de que forma ela pode ajudar na refundação do Direito segundo o aspecto ôntico do humano.

A compreensão da autopoiese do ôntico-humanista proporcionará uma nova forma de pensar-se e aplicar-se o Direito. Conforme Meneghetti ${ }^{3}$, o critério é o "princípio ou elemento que constitui o conforme ou disforma uma coisa, a um projeto, a uma ação etc.". Esse princípio é o Em Si ôntico, o Em Si do ser, o Em Si que é o modo ou forma que é critério. Logo, por episteme, Meneghetti entende por "semente, raiz ou que é próximo, íntimo ao princípio em si”. Portanto, é possível refundar-se o Direito segundo a "atualidade da causa primeira de um processo" humanista.

Enfim, é possível pensar-se o Direito com base nas premissas ontopsicológicas para que os seus operadores atuem em base a uma lógica humanista. O objetivo é o de que o Direito, em suas aplicações racionais, seja justaposto como instrumento da evolução humana, conforme uma ordem superior de organização individual e social.

\section{Fundamentação Teórica}

\subsection{Direito e Ontopsicologia}

O ser humano é constituído, naturalmente, por um princípio formal inteligente, o Em Si ôntico. Meneghetti (2013, p. 39) o define como o projeto-base de natureza que constitui o ser humano. O autor define "projeto" como um modo de ação, um protótipo que

\footnotetext{
3 MENEGHETTI, Antonio. Dicionário de Ontopsicologia. 2. ed. rev. atual. Recanto Maestro: Ontopsicológica Editora Universitária, 2012.
} 
se faz da racionalidade a todo contexto.

Meneghetti (2007, p. 32) afirma que o homem ${ }^{4}$, enquanto ser humano possui forma apriórica transcendente e, também, a evidência da ecceidade ${ }^{5}$ histórica. Ou seja, o Em Si ôntico é parte do horizonte do ser, sendo a mediação entre o ser e a existência. O Em Si ôntico ocorre no ser, mas se manifesta, individua-se, através das ações históricas no plano concreto (autócticse histórica).

Ainda conforme Meneghetti (2007, p. 32), o Em Si ôntico, princípio formal que faz autóctise histórica, por ser um critério da ordem do ser, nutre-se, metaboliza somente aquilo que lhe é conforme, símile, igual. Isto é, para o Em Si ôntico o justo é verdadeiro. ${ }^{6}$ Meneghetti (2007, p. 32) explica que “a metabolização do Em Si ôntico consiste em escolher o possível para si mesmo, e o critério de escolha é o princípio de sua identidade. Por isso, a justiça, no que se refere ao Em Si ôntico, é exclusivamente aquilo que é conforme à própria identidade.”. Logo, conforme o autor, tudo o que é útil e funcional a identidade concebe-se como a verdadeira moral. ${ }^{7}$

O Em Si ôntico, por ser uma identidade de natureza fornecida pela vida, possui um modo de agir particular, igual à própria essência, no sentido de que deve ser vantajoso à identidade que ele próprio é. Meneghetti (2013, p. 40) ressalta que a ética de comportamento $^{8}$ é aquela projetada pela identidade essencial, por isso apresenta o primeiro critério: utilidade. É possível vislumbrar a utilidade quando, em determinada situação, uma pessoa depara-se com múltiplas escolhas o Em Si ôntico irá indicar aquela que melhor lhe aprouver, a mais útil à própria identidade, ou seja, irá informar ao sujeito a escolha otimal para o momento, cabendo ao receptor percebê-la e executá-la.

\footnotetext{
${ }^{4}$ Meneghetti (2012, p. 128) conceitua homem da seguinte forma: "unidade de ação histórico-espiritual constituída por um projeto ôntico em acontecimento terrestre, com faculdades ou funções inteligentes, racionais, emocionais, biológicas".

${ }^{5}$ Sobre a ecceidade, Meneghetti (2010, p. 84): "Duns Scotus, denominado Doctor Subtilis (o "Doutor Sutil"), introduz conceito importantíssimo de haecceitas, a ecceidade. O conceito de ecceidade define o ente individual: é o conceito de existir, do ser aqui e agora".

${ }^{6}$ Meneghetti (2007, p. 32) explica que: "Para o homem, enquanto Em Si ôntico, justo deve ser verdadeiro, porque o Em $\mathrm{Si}$ ôntico, sendo um critério participado da ordem do ser (o real transcendente por si consistente), não se nutre de algo que seja diverso, oposto a si: metaboliza somente aquilo que lhe é conforme, igual. A metabolização do Em Si ôntico consiste em escolher o possível para si mesmo, e o critério de escolha é o princípio de sua identidade. Por isso, a justiça, no que se refere ao Em Si ôntico, é exclusivamente aquilo que é conforme à própria identidade. Conseqüentemente, tudo aquilo que é útil e funcional a essa identidade é a verdadeira moral".

${ }^{7}$ Atualmente, muito são utilizadas palavras como "ética", "Direito" e "moral", mas que não se sabe a real epistemologia das expressões. Sobre a temática Meneghetti (2004, p. 165-166) relata: "Para uma compreensão mais fácil, considero indispensável uma reconfiguração dos termos com os quais farei esta exposição, porque hoje se usam palavras como "ética", "Direito", "moral", mas não sabe bem que sentido tenham: de fato, perdemos as linhas de partida e, por isso, a confusão é gratuita".

${ }^{8}$ Meneghetti (2012, p. 56) conceitua comportamento como a "Fenomenologia do Eu lógico-histórico".
} 
Adstrita ao que é útil tem-se a funcionalidade, definida por Meneghetti (2013, p. 40-41) como a segunda categoria da ética do Em Si ôntico. Essa identidade busca continuamente aquilo que é útil e funcional para si. Utilidade e funcionalidade são critérios imanentes para melhor definir escolhas profícuas e compreender o real sentido da vida.

Para que se possa conviver no sistema do Direito, fazer o jogo social necessário, mas decidir optando pela escolha otimal deve-se conhecer e metabolizar a função da dupla moral $^{9}$. Meneghetti (2013, p. 44-45) elucida a dupla moral ${ }^{10}$. Encontramo-nos dentro de um constante jogo de existência dualista: a moral da sociedade e a moral da vida. A moral da sociedade $^{11}$ é aquela em que o sujeito convive com outras pessoas diretamente, recebendo e interagindo com as influências destas, podendo ele ir a favor dos preceitos e figurações por elas passados.

Em boa parte da vida, a influência da cultura social contraria o próprio projeto de vida. Moral e ética podem ser entendidas de modo diferente em termos de lugar e de tempo, pois, a exemplo, os costumes de uma tribo indígena ou dos esquimós não são os mesmos, mas, de qualquer forma, dentro desses povos devem ser respeitados.

Conforme Meneghetti (2002, p. 29), para a sociedade, o critério ético é o que a lei ou a opinião pública estabelece como verdadeiro ou falso. Nesse caso, a ética é entendida como um modo de comportamento estabelecido por lei, portanto, o critério é critério legal, é onde a lei discrimina o bom e o mau, o certo e o errado, o pró e o contra. Porém, ainda de acordo com o autor, o bem e o mau no interior de um critério legal são relativos à história e ao modo de pensar, são conexos com a relatividade do Direito positivo.

A partir dos ensinamentos do mesmo autor, constata-se que, na realidade, o bom e o mau são verificados pelos resultados sociais: se uma lei - uma vez delineada conforme a

\footnotetext{
${ }^{9}$ Meneghetti (2004, p. 164) sobre a dupla moral na área do Direito: "Sem dúvida, será uma terapia de confronto para depois começar a entrar no conceito de dupla moral: uma interior, que é aquela fundamental, e uma externa, para fazer o que é possível segundo as estruturas sócio-jurídicas da história”.

${ }^{10}$ Meneghetti (2010, p. 42) ensina que o Eu lógico-histórico possui duas regras. A primeira é realizar a si mesmo externamente sem contradizer os estereótipos sociais e a fenomenologia histórica. A segunda regra informa que o Eu lógico-histórico representa o equilíbrio da dupla moral. Isto é, o Eu lógico-histórico deve construir o caminho à lógica da água do rio, que transcorre conforme o leito até chegar ao mar. O Eu lógicohistórico deve salvar a sociedade e sua inseidade metafísica, não podendo destruir a sociedade e o Em Si ôntico.

${ }^{11}$ Ao nascer, cada sujeito inicia sua passagem pela vida em um cotidiano já emoldurado, com estereótipos, vícios, certezas e incertezas. A sociedade "impõe" qual o modo correto de vestir-se, quais os costumes a serem seguidos e até mesmo o que se deve cultuar. Muitas vezes, essas informações mais denigrem um ser humano na sua essência do que o preservam acerca das leis da vida, veja-se, como exemplo, o delinquente, que sobre ele a rigidez de uma moral produz reações antissociais, a ponto de querer ser morto para tornar-se liberto do cárcere corporal.
} 
intencionalidade da vida - facilita a produção e bem-estar, então é boa, do contrário, é negativa. Frequentemente, o assim chamado "senso comum" é um plágio do superego, não é uma essência da natureza. Isso confirma que a verdade não muda, seja se a creem todos, seja se não a crê ninguém.

Nessa senda, deve-se entender que o Direito é sadio se produz efeitos em conformidade a vida. A lei possui o objetivo de regulamentar a sociedade sob determinada perspectiva e produzir o bem através de sua aplicação. Meneghetti $(2004,170)$ dispõe que o primeiro bem da lei é o coletivo, secundário o indivíduo. Mesmo que o indivíduo seja parte da ordem social, a lei tutela o bem jurídico do conjunto, entretanto, para resguardar a coletividade, não pode deslembrar do sujeito enquanto individualidade.

O senso comum é um critério político, democrático, sociológico, mas não pode ser um critério base para dar garantia à racionalidade de um homem superior no exercício histórico da sua evolução liderística. Meneghetti define que, no entender da sociedade, o critério ético é aquele dito verdadeiro ou falso conforme disposto pela lei ou pela opinião pública.

Especificamente, Meneghetti (2004, p. 169) informa a diretiva para transcender ao raciocínio comum:

\begin{abstract}
No amontoado de confusão atual sobre o Direito em geral, cabe exclusivamente aos seus gestores autenticar a episteme da funcionalidade e - após uma autenticação individual - advertir e orientar a liberdade social. Não adianta refugiar-se atrás da horda da violência do número. A democracia é a violência do número, visto que as prevalências democráticas são baseadas em votos, não na racionalidade dos fatos: trata-se, portanto, da maioria do número, não da inteligência. Certamente devemos aceitá-la, mas um jurista profundo - na sua raiz - não pode refugiar-se atrás da horda da violência do número, porque significaria exercer a razão da força e não a força da razão integral, a qual é a divina proporção entre os opostos.
\end{abstract}

O critério fundante da racionalidade jurídica concorde ao Em Si ôntico deve ocorrer à luz da interpretação de um profissional que seja autêntico. Ser autêntico significa agir conforme o projeto de natureza, conforme a identidade. O jurista deve proporcionar a reversibilidade das informações emitidas pelo Em Si ôntico através de ações históricas pelo Eu-lógico histórico. Primeiramente o profissional do Direito deve consentir a autenticação $^{12}$ individual, e, posteriormente, verificar a episteme da funcionalidade para

\footnotetext{
${ }^{12}$ Conforme Meneghetti (2012, p. 29) autenticação significa: "Quando a ação se testemunha exclusivamente pelo próprio fazer-se ou dar-se.

Uma coisa ou um contexto é autêntico quando se demonstra por como o ser se presencia (em antecipação a qualquer configurado racional ou lógico).
} 
orientar e mediar o interesse do cliente ao objeto jurídico protegido pela lei.

O dever dos gestores do Direito é autenticar a episteme da funcionalidade do Direito diante da confusão social. Apesar dos méritos do sistema democrático, é latente a conclusão de que a democracia é a imposição do número (vox populi, vox Dei) e também uma convenção humana, em que a afirmação da vontade da maioria dos integrantes de uma sociedade determina o seguimento. É um sistema de controle social e o jurista não pode abnegá-lo, sob pena de ser enjeitado socialmente. Na democracia nem sempre prevalece a racionalidade dos fatos, por isso, verifica-se tratar da maioria do número, não da inteligência. Todavia, o jurista não pode residir às sombras da violência do número, pois assim estaria a exercer a razão da força e não a força da razão integral.

É ainda mais ardiloso e sensível o labor dos gestores do Direito que se propõe a buscar o real da vida. Poucas pessoas conseguirão libertar-se das amarras estereotipadas para alcançar o nexo ontológico entre o mundo dos fatos e o mundo da vida ${ }^{13}$. É minucioso o processo de autenticação e refundação necessário ao Direito, pois o critério da mudança parte da interioridade do profissional e projeta o resultado de forma consequencial. Se o jurista é autêntico, utiliza o corpo como expressão da alma, o resultado é perfeito ao objetivo pretendido. Entretanto, caso o jurista não seja autêntico, o resultado será o prosseguimento das interpretações distorcidas e fora da arquitetura da vida.

A metabolização do Em Si ôntico ocorre através da realização da escolha vencedora de cada momento, a qual deve estar assentada em um critério, qual seja: critério de natureza (procede-se por evidência). Na Ontopsicologia, admite-se somente o critério de natureza. Dessa forma, pode-se concluir que ao proceder-se por evidencia, age-se conforme a verdade que é interna ao ser humano. É por este motivo que a Ontopsicologia está vinculada ao Direito natural ontológico, ou seja, ao Direito que possui a base natural originária do ser.

Para Meneghetti (2007, p. 34) a verdade é concebida como a realização do projeto

O sinal é autêntico quando se configura igual à coisa.

Conformar o Eu lógico-histórico à intencionalidade do Em Si ôntico.

Capacidade de desenvolver-se segundo a própria intrínseca virtualidade. Elementaridade formal de executar o cumprimento da própria posição virtual como indivíduo”.

${ }^{13}$ Gómez-Heras (1989, p. 249), diz que o mundo-da-vida é "o mundo de onde se nasce e morre; se herda uma tradição cultural; se comunica uma linguagem (língua) e se convivi com os outros. O mundo-da-vida é configurado historicamente por um passado e um presente, transmitidos por tradições e expressados pela linguagem. É o mundo de nossa cotidianidade, cujo horizonte nos enquadramos para nos orientarmos e, por sua vez, tecemos as relações sociais nas quais nos relacionamos uns com os outros". 
de natureza arquitetado pela vida, e como individuado pelo Em Si ôntico. É a realização da individualidade pela qual cada ser nasceu para cumprir, que é distinta a de qualquer outro similar em existência. A verdade do homem é ser igual a intencionalidade projetada pelo ser na existência configurada. Meneghetti (2007, p. 34) descreve que "o sumo de um homem está no exaurimento daquele virtual que já é identificado, posto na ecceidade individuada pela sua pessoa". ${ }^{14}$

Porquanto, o justo e a verdade convergem entre si quando alinhados à intencionalidade de natureza do ser humano. O Em Si ôntico é o critério que informa a identidade de natureza, informa a utilidade e funcionalidade em cada relação e ocasião. Meneghetti (2007, p. 36-37) afirma que existe um princípio ontológico do Direito e da justiça. Segundo o autor, este princípio ocorre no plano concreto a cada vez que um comportamento humano é imposto ou negado, desde que agido através do nexo ôntico.

O jurista é o mediador entre a lei e a vida de seu cliente. A lei é fixa, mas o espírito da lei é dinâmico, variável. O jurista deve ajustar os recursos que a vida dispõe em relação aos instrumentos da lei. Tem-se um comportamento ambivalente: de um lado o cumprimento da lei, do outro, a necessidade de privilegiarem-se as necessidades da vida. $\mathrm{O}$ jurista deve utilizar o critério da vida como fundamento racional da construção de soluções para demandas jurídicas.

Meneghetti (2007, p. 36) é muito claro ao referir, dentro desse contexto, que a “conformidade ao projeto existencial é a união com o ser". A interpretação e aplicação das leis devem ocorrer em favor da existência humana, em conexão com o ser, pois quando um preceito legal é cumprido surge o cumprimento de uma dupla função, o sujeito estará junto a comunidade, não será reprovável socialmente, e obterá ganho de proteção jurídica e existencial para si.

Diante disso, para Meneghetti (2007, p. 37), o princípio ontológico do Direito e da justiça é o Ius, entendido como "o princípio de como se relacionar a outro (id quod est ad aliud). Ius é o verdadeiro do igual 'a', por isso tem autenticidade ou submissão. 'A' é a relação à identidade operante". O sistema social, bem como o Direito, realiza-se a partir de

\footnotetext{
${ }^{14}$ Meneghetti (2007, p. 34): “A 'verdade' apela-se à posição do existir ordenada pelo ser: é um existir para a realização. A verdade, portanto, é relativa à realização do homem enquanto proposta feita pela vida, pelo ser, portanto a verdade do homem é o igual com a intencionalidade do ser naquela existência configurada. $\mathrm{O}$ sumo de um homem está no exaurimento daquele virtual que já é identificado, posto na ecceidade individuada pela sua pessoa. Essa seria a 'primeira moral', a moral da vida, do ser. 'Moral' significa 'comportamento conforme a'. Se o homem vive essa moral determinada pela virtualidade do próprio Em $\mathrm{Si}$ ôntico, tem a paz, a completude, a beatitude, o contato com o ser, com aquele princípio que o motivou, que o colocou em curso".
} 
relações intersubjetivas ${ }^{15}$. Portanto, o Ius é a premissa ontológica do Direito e da justiça que o jurista deve implementar no seu ferramental de ações profissionais, pois informa como se relacionar com outras pessoas que tenham interesses convergentes ou divergentes em relação a um mesmo objeto.

Importa destacar que o Ius é definido por Meneghetti como "o verdadeiro do igual 'a'”. Nas relações jurídicas travadas pelos seres humanos, em primeiro lugar, deve-se manter atento e auscultar a resposta organísmica, a reação visceral. Meneghetti (2010, p. 242) informa que "o homem congruente a sim mesmo, no momento do impacto didático, deve auscultar o próprio sinal organísmico, como a relação retorna ao seu radar viscerotônico".

Meneghetti (2010, p. 242) é categórico e muito claro ao afirmar que "se o sinal retorna ressoante e ampliador, pode-se começar a confiar. Ao contrário, advertindo um frio, uma rigidez, uma conexão de articulações metálicas, o sujeito deve se fechar e ir embora". O autor entende que a cada momento e em cada relação, é preciso estar em estado em guarda para ser exato e não se deixar influenciar por informações de terceiros ou mesmo perder a diretiva da vida a ser aplicada no evento. Por estar em guarda, Meneghetti trata do cuidado ao miricismo cotidiano dos impactos, as especificidades das relações emotivas (modo de sorrir, apresentar-se, expressar-se etc.).

O objetivo é demonstrar ao jurista que para encontrar a verdade e ser justo, é preciso, antes de qualquer ação, ser exato e fiel a si mesmo. Compreender e seguir o seu projeto de natureza. O fundamento da atuação profissional deve ocorrer em base a arquitetura emoldurada pelo Em Si ôntico. Conduto, para que isso ocorra, é preciso percorrer o trajeto em que se necessita despir-se de estereótipos ${ }^{16}$ e distinguir as distorções proporcionadas pelo Monitor de Deflexão. É imanente o trabalho conjugado às três descobertas da Ontopsicologia.

É importante esclarecer que o trabalho do jurista não se limita a leitura, interpretação e aplicação das fontes do Direito, é mais que isso, especialmente àqueles que se dedicam ao ofício artesanal. As atividades jurídicas, todas, demandam a interação com

\footnotetext{
${ }^{15}$ Meneghetti (2009, p. 67), atribui ao Direito forte influência nas relações intersubjetivas travadas entre pessoas, e também naquelas entre Estados. O autor refere que: "O Direito é a primeira arma universal que a inteligência racional constrói. Ele estabelece o justo e o injusto, distingue aquilo que pode daquilo que não pode. É a arma onipotente da psique humana, que depois a sociedade fenomeniza em nível mundial”.

${ }^{16}$ Para Meneghetti (2012, p. 99) o estereótipo possui o seguinte significado: "Um modelo de comportamento geral que se faz referência de outros semelhantes e que se torna valor de apoio para individuar seguranças e razão dialética com a sociedade".
} 
interesses divergentes ou convergentes, e normalmente em situações conflituosas. Meneghetti (2011, p. 278) confirma que as armadilhas cotidianas do conflito podem ser ultrapassadas mediante a utilização de dois princípios: 1) evitar o ódio; e 2) nunca se apropriar daquilo que não é próprio.

Ainda conforme o mesmo autor, é possível concluir que a atuação pautada nestas duas premissas básicas permite o acesso racional a duas outras premissas essenciais para uma performance resolutiva do conflito: 1) racionalidade material da coisa; e 2) racionalidade jurídica. É preciso compreender a causalidade do evento despindo-se do ódio e sem apropriação das informações que não são do sujeito, objetivando-se um panorama exato do conflito e, através disso, a solução otimal de acordo com uma racionalidade jurídica justa e verdadeira.

Seja em relação ao cliente, seja em relação a terceiros que estejam envolvidos pelo interesse do contratante, o fato é que o jurista nunca deve deslembrar de três critérios fundantes das díades para ler a solução otimal, que são assim definidos por Meneghetti (2010, p. 242): auscultar a resposta organísmica; em cada impacto relacional é preciso ter sempre claro em si o escopo, a motivação daquela díade; e manter o próprio profissionalismo e uma profunda dignidade de si mesmo.

O jurista, para adentrar nesta esfera de conhecimento, precisa dominar três pressupostos basilares, quais sejam: saúde (biológico ${ }^{17}$ ); saúde psíquica (nous/mente); e base econômica. A saúde não se refere somente ao pleno funcionamento do organismo, é também, mas não só, pois o corpo é o livro da alma. Isto é, o homem sadio é aquele que possui o corpo saudável em decorrência da sua autóctise histórica conforma ao projeto ôntico. O homem é sadio quando consegue executar as informações provenientes da vida. A saúde psíquica (nous/mente) é obtida através da capacidade do sujeito conseguir executar através do Eu lógico-histórico as informações emanadas pelo Em Si ôntico. Por fim, o jurista deve ter uma base econômica. O sustento de todas as necessidades humanas, desde as mínimas necessárias até as de puro deleite, assim como da estrutura material/profissional, exigem que o jurista possua uma fonte econômica de sustento, pois através dela as atividades seguirão mediante atos planejados e não por pura necessidade.

Destaca-se que o principal pressuposto é a base biológica humana. É, também, uma das maiores contribuições da Ontopsicologia para o campo do Direito. Através da

\footnotetext{
${ }^{17}$ Meneghetti $(2010,72)$ atribui à palavra biológico o conceito de "a lógica de natureza".
} 
percepção ${ }^{18}$ da base biológica pelo campo semântico, abre-se o conhecimento para um universo racional desconhecido pelos profissionais do âmbito jurídico.

Toda a passagem para a resolução de um problema/situação pode ocorrer através da percepção e leitura das informações transmitidas via campo semântico. Meneghetti (2010, p. 32) ensina que "a percepção do campo semântico é uma experiência cotidiana e natural, própria de qualquer vivente, variável.” A experiência do campo semântico é possível para pessoas que sejam autênticas, que conheçam e reconheçam as informações do próprio Em Si ôntico, a fim de que não haja confusão de intencionalidades que não lhes sejam próprias.

Para Meneghetti (2010, p. 32) o primeiro momento do campo semântico é a atividade psíquica (primeiro e fundamental mover-se do homem). Para o autor "o campo semântico é uma variável da atividade psíquica, é o projeto momentâneo da semovência psíquica.". O autor entende que a atividade psíquica é sempre invisível, como, por exemplo, o próprio pensamento e a consciência, que são fenomenologias e não se consegue ver a causa em si. A consciência humana lê em fenomenologia.

Através da prática clínica, Meneghetti (2010, p. 32) conseguiu verificar a existência de diversas vetorialidades, as quais isolou, e identificou que eram provenientes de uma pulsão. O resultado prático demonstrou-se dicotômico. Nas ocasiões em que as pulsões eram percebidas, e também a sua intencionalidade, e foram atuadas no plano prático, certificava-se um resultado positivo para o sujeito. Por resultado positivo o autor refere-se a autorrealização como equilíbrio, saúde, progresso, funcionalidade. Entretanto, quando a pulsão fosse desacreditada, o sujeito sofria uma perda (pessoal ou profissional), desiquilíbrio existencial ou biológico-funcional.

É dentro deste aspecto de experimentação clínica, que Meneghetti (2010, p. 33) conclui que a base fundante do critério epistêmico não é composta somente pela evidência, pois ela é o ponto de chegada. A evidência é o resultado da aplicação de dois critérios metodológicos: identidade e funcionalidade utilitarista. A identidade é aquilo que o ser humano é aqui e agora. Já, a funcionalidade utilitarista, conforme Meneghetti (2010, p. 33 34) caracteriza-se por "individuar e selecionar todas as coisas que aumentam essa identidade e distingui-las de todas que a diminuem".

$\mathrm{O}$ autor constata que a base das decisões ocorre com esses dois critérios racionais. Da tomada de decisão com lastro nos critérios metodológicos é possível homologar o

\footnotetext{
${ }^{18}$ Meneghetti $(2010,210)$ assim conceitua a palavra percepção: "atitude para receber ou captar a ação e mensurar-lhe o valor. Atitude para receber e reconhecer a informação concretamente ou em símbolo".
} 
projeto de vida. ${ }^{19}$ Meneghetti (2010, p. 33) diz que "é verdadeiro e certo tudo aquilo que dá funcionalidade utilitarista e biológica em sentido concreto". Quando se identifica o Em Si ôntico, é sadia e verdadeira a informação que pode ser conformada ao projeto de existência. Contudo, aquilo que é diferente da arquitetura da vida é doença, contra o sujeito.

Uma constatação de todas estas considerações, é que a contribuição da Ontopsicologia para o Direito somente poderá ser acessada pelo jurista que assume, enquanto obra da vida, o compromisso de realizar seu projeto natural, relativizando os estereótipos introjetados e tornando-se autêntico. Para que se possa viver esta realidade, é necessário alcançar a sanidade biológica, pois toda a aplicação da Ontopsicologia no Direito perpassa pela integridade física e mental da pessoa do jurista, que depois irá identificar a necessidade, intenção e resolução que o cliente ou evento necessita.

Em que pesem estas ponderações, hodiernamente, é possível vislumbrar, em especial na juventude acadêmica do curso de Direito, que existe uma crise racional na forma de pensar e aplicar o Direito. Fatidicamente, o Direito é instrumentalizado para operar em desfavor da evolução humana, sob a máxima do homo homini lupus, haja vista de que, muitas vezes, o arcabouço normativo é utilizado pelo homem e contra o homem.

A realidade jurídica vivenciada transborda no sentido da responsabilização do Estado e das instituições como responsáveis pela resolução dos problemas (pessoais ou profissionais). Isto é, as pessoas transferem responsabilidades personalíssimas ao Estado e instituições buscando soluções individuais, ignorando a responsabilidade que incumbe a cada ser humano.

Em face desta crise, Meneghetti (2004, p. 164) refere que é necessário transcender os costumes habituais para que haja um reposicionamento da mente sobre a existência e contemplação da natureza humana, em suas palavras:

É necessário, antes de tudo, fazer transcendência do habitual, de tudo o que está impregnado no sócio-econômico-jurídico que nos direciona. É necessária uma transcendência para requalificar a nossa posição mental sobre a contemplação da ordem maravilhosa da natureza, sobre o primado da inteligência do homem que se constitui responsável primário deste planeta, e para reativar aquele algo de sábio depositado no próprio fato de que nós existimos como homens jurídicos.

Meneghetti (2004, p. 165) propõe a refundação da ciência jurídica e do

\footnotetext{
${ }^{19}$ Projeto de vida e projeto de natureza são expressões sinônimas ao conceito de Em Si ôntico.
} 
comportamento social. Para o autor é possível recomeçar do início aceitando como critério de refundação epistêmico a autopoiese do ôntico-humanista. Meneghetti entende que é necessário reconfigurar a ciência e os termos utilizados atualmente, pois, segundo o autor, atualmente usam-se as expressões como "Direito", "ética" e "moral", mas não se sabe o correto sentido, portanto, instaura-se uma confusão dos termos e de quem os utiliza.

\title{
2. 2 O critério de refundação epistêmico segundo a autopoiese do ôntico-humanista
}

Para Meneghetti é possível refundar o Direito com base no critério epistêmico segundo a autopoiese do ôntico-humanista. O nexo entre a ciência jurídica e ciência ontopsicológica está contido na interpretação e aplicação da autopoiesis do ônticohumanista. O grande questionamento a ser respondido repousa sobre como conjugar e aplicar as duas ciências à luz deste fundamento.

Meneghetti (2004, p. 166) entende que o primeiro e fundamental princípio é a ética, pois dela dependem as morais, as leis e o Direito-dever. Conforme o autor, a ética caracteriza-se por ser o conjunto das morais ou códigos. De outro lado, a moral é o “conjunto das leis representadas pelo código". Por fim, a lei que articula o Direito-dever.

Meneghetti caracteriza a ética como sendo a ciência ${ }^{20}$ dos comportamentos humanos. Meneghetti (2004, p. 166-167) discorre sobre o objeto formal da ética, caracterizando-o da seguinte forma:

\begin{abstract}
Objeto formal da ética é o ato humano prático, portanto a ética é a ciência diretiva dos humanos segundo a ordem racional prevista pela natureza. Isso, obviamente, remete ao momento autopoiético ôntico-humanista. Autopoiético (do grego = "si mesmo"; = "fazer") é uma autoposição, um auto-fazer-se. A célula, em sentido biológico (esse não é um exemplo, mas uma referência concreta, põe-se por si, é um a priori irrefutável; qualquer que seja o modo ou a arte clínica dos médicos, a célula é apriórica a todas as determinações, as hipóteses, as elaborações ou as cirurgias. O orgânico racional ao qual me refiro é algo semelhante e encontra-se no humano conforme a como a natureza estruturou biológica e geneticamente.
\end{abstract}

Ainda conforme o mesmo autor, o Direito pode garantir-se na medida em que confirma e acentua a capacidade de autorregulação e autopoiese da ordem biológica humana. Isto é, o Direito possui fundamento se resguarda a autonomia autopoiética da racionalidade humana, que lhe serve de fundamento.

A autopoiese foi objeto de estudo do biólogo chileno Humberto Maturana e do

\footnotetext{
${ }^{20}$ Meneghetti (2004, p. 166) sobre o conceito de ciência: “"ciência' para mim é um saber a ação com o ser: o ser concreto, real, aqui e agora, aquilo que faz o real, fá-lo ser ou não ser [...]”.
} 
médico chileno Francisco Varela. Andrade (2012, p. 98) sustenta que a preocupação central da autopoiesis ${ }^{21}$ não ocorre somente quanto à realidade e a existência do mundo, mas também sobre a forma como o ser humano interpreta o mundo e compreende a realidade. Para a autora a autopoiese também trata da compreensão de como compreendemos, enquanto humanos e observadores. ${ }^{22}$

De acordo com a autora em citação, autopoiesis considera que o conhecimento humano provém de uma correlação interna. Esse encadeamento interno é responsável pela forma de como atribuímos sentido à realidade externa. Portanto, fica claro que a realidade das informações não existe de forma apartada do observador. Quando se trata da figura do observador, está-se relacionando a sua composição biológica, organísmica, que é uma condição imanente a todo ser humano e que dispõe das condições de interpretação da realidade interna e externa ao ser. Assim sendo, para a teoria da autopoiesis, é o observador que atribui sentido à realidade, a partir das suas correlações internas.

Contudo, é a partir da dinâmica interna e do meio que se pode chegar ao entendimento completo do observador. Maturana e Varela (1995, p. 165) apresentam sua teoria nesse mesmo sentido:

Nenhum desses dois domínios possíveis de descrição é problemático em si, e ambos são necessários para um entendimento completo da unidade. É o observador que os correlaciona a partir de sua perspectiva externa. É ele quem reconhece que a estrutura do sistema determina suas interações ao especificar quais configurações do meio podem desencadear mudanças estruturais no sistema. É ele quem reconhece que o meio não especifica nem informa as mudanças estruturais do sistema.

A cognição ocorre através do corpo físico do ser humano, que possibilita a nossa correlação interna. Entretanto, Maturana e Varela atribuem ao observador/pesquisador uma responsabilidade muito significativa para a exatidão do estudo e da ciência. Isto é, os

\footnotetext{
${ }^{21}$ Deve-se salientar que a autopoiesis foi criada em base a fundamentos biológicos.

${ }^{22}$ Andrade (2012, p. 98) apresenta um exemplo citado por Maturana e Varela acerca do processo cognitivo: "Para exemplificar o entendimento acerca do processo cognitivo, Maturana e Varela usam como exemplo o experimento da salamandra realizado por um biólogo norte-americano em 1943. A salamandra é um anfíbio com alto poder de regeneração. Se cortarmos sua cauda ela se regenera e, mais espantoso, é que se cortamos seu nervo óptico, ele também se regenera, ou seja, a salamandra recupera sua visão. Podemos, até mesmo, retirar completamente seu olho e colocar de novo que o nervo óptico se cicatriza e se regenera. Porém, o mais interessante neste experimento é que ao giramos o olho da salamandra em $180^{\circ}$ e colocarmos um inseto em sua frente, a salamandra lança sua língua para trás e erra sua pontaria. Isso acontece porque ao girarmos o olho da salamandra a retina posterior se desloca para frente ficando no lugar da anterior, e vice-versa; da mesma forma que acontece com a retina superior que fica embaixo e com a inferior que vai para cima. O que esse experimento indica, portanto, é que "o ato de lançar a língua e capturar o bichinho não é um ato de apontar para um objeto externo, mas de fazer uma correlação interna" (2001, p. 19)".
} 
autores atribuem o encargo ao pesquisador da necessidade de correlacionar o meio e a dinâmica interna para obter a real compreensão do externo e, a partir disso, a emanação de uma pesquisa pautada em sua percepção.

O pesquisador/observador deve ser exato em seu trabalho, pois um estudo que pode influenciar outros estudiosos ou uma ciência transcorre do seu pensar. Portanto, é uma responsabilidade pessoal do observador ao calibrar a interação entre o meio e as sinapses internas.

Para a Autopoiesis, não se desconsidera a influência do meio sobre a autonomia do ser humano, em que pese a estrutura biológica já ser determinada e autônoma. Sobre a interação do organismo e do meio Maturana (2002, p. 62) correlaciona da seguinte forma:

\begin{abstract}
Em outras palavras, organismo e meio desencadeiam mutuamente mudanças estruturais sob as quais permanecem reciprocamente congruentes, de modo que cada um flui no encontro com o outro seguindo as dimensões em que conservam sua organização e adaptação, caso contrário, o organismo morre. Finalmente, isso ocorre espontaneamente, sem nenhum esforço dos participantes, como resultado do determinismo estrutural na dinâmica sistêmica que se constitui no encontro organismomeio. Em consequência disto enquanto estou vivo e até que morra, vivo em interações recorrentes com o meio, sob condições nas quais o meio e eu mudamos de maneira congruente. Isto é sempre assim? Sim, sempre!
\end{abstract}

Maturana explica que o organismo humano vive, naturalmente, em interações com o meio que o rodeia. Meio e organismo convivem de forma recíproca e congruente, conservando sua organização e adaptação. $\mathrm{O}$ autor ainda diz que se não existisse essa interação haveria a morte do organismo. Dessa forma, percebe-se que apesar da estrutura orgânica ser autopoiética, é imprescindível sua interação com o meio onde se situa.

É muito claro que o entendimento de Maturana é o de que o ser humano convive em um meio e com ele está em interações recorrentes. Esse processo repete-se enquanto o organismo estiver vivo e o efeito é a mudança em ambas as ordens. Esse fenômeno foi chamado por Maturana e Varela como ontogenia. A ontogenia é caracterizada como sendo as mudanças estruturais que ocorrem nos seres vivos entre o surgimento e a morte.

Atribui-se às células a organização autopoiética, sendo esta condição que lhes permite conferir a condição de autônomas. Os seres vivos se fundam em unidades devido a organização autopoiética, a qual confere a identidade de seres vivos. Andrade (2012, p. 113) define que "é nesse sentido, que a autopoiesis considera os seres vivos como unidades autônomas, pois eles se autocriam, se autoproduzem, se realizam e se especificam a partir de uma organização que os define como unidades.”. E mais, a autora afirma que a 
fenomenologia biológica é autônoma por ser autopoiética, sendo que à natureza física compete, tão somente, a determinação espacial, a determinação do espaço físico em que a unidade desenvolver-se-á.

Para Maturana, o comportamento humano, nas diferentes esferas, é biológico e da vida. O comportamento social seria determinado pelo biológico humano, uma vez que a conduta social é influenciada pelo comportamento das pessoas, dos elementos que interagem entre si. Na visão do autor em referência, um sistema biologicamente determinado não está isento dos complexos sociais, culturais, bem como dos eventos proporcionados pelo meio. Portanto esse sistema biologicamente determinado, possui uma autonomia autorreguladora que é capaz de definir a realidade em que se encontra inserida.

É de conhecimento notório que os seres vivos possuem algumas diferenças estruturais, a depender da espécie, porém, a estrutura celular é a mesma. Logo, esta estrutura é o produto para que algo possa existir. Maturana e Varela (1995, p. 87) concluem que "os seres vivos se caracterizam por sua organização autopoiética. Diferenciam-se entre si por terem estruturas diferentes, mas são iguais em sua organização". A partir do fragmento transcrito, é possível constatar que nem toda organização é autopoiética, pois o que define como tal é a possibilidade de reproduzir-se continuamente, a capacidade de autocriação dos seres vivos através das estruturas celulares e do processo ontogênico.

Maturana e Varela utilizam-se do exemplo das moléculas de silicone, as quais apesar de situarem-se dentro do corpo humano e estarem organizadas dentro da estrutura humana, não são consideradas unidades autopoiéticas. A classificação de unidade autopoiética implica diretamente a identificação como ser vivo. Porquanto, será considerado como unidade autônoma, capaz de autocriar-se. A unidade autopoiética é geradora de si mesma na própria organização.

O ponto de encontro entre a autopoiésis de Maturana e Varela e a Ontopsicologia está na proposta de refundação da ciência jurídica em base ao critério epistêmico segundo a autopoiese do ôntico-humanista. Meneghetti assume o sentido biológico da palavra autopoiese para conjugá-la à possibilidade de reestruturação do Direito através da impressão na lei e à interpretação do Direito com base em uma arquitetura anterior ao homem e que não foi criada pelo Direito. ${ }^{23}$

\footnotetext{
${ }^{23}$ Meneghetti (2004, p. 168): "Se quisermos ter a sanidade devemos nos apelar a um princípio que já é préconstituído no nosso holístico, no nosso "aqui”, no nosso sínolo histórico".
} 
Meneghetti (2004, p. 168) explica o critério de refundação da seguinte forma:

Defini tal critério como 'autopoiético', 'ôntico', 'humanista'. Autopoiético: posiciona-se por si, como a célula. Ôntico: como existente, venho de algo que é o princípio do real, o Ser. Humanista: não é um ôntico genérico, mas em autopoiese à minha estrutura de homem.

Dessa forma, de acordo com Meneghetti (2004, p. 178) a episteme ${ }^{24}$ da funcionalidade do Direito deve ser buscada na "intencionalidade de natureza do ôntico-humanista, segundo a evidência práxico-biológica do Em Si ôntico, a ser revelado com a metodologia ontopsicológica". O critério é autopoiético por seguir a ordem da natureza, o princípio da vida. É ôntico por ser proveniente do Ser, daquilo que é real, verdadeiro. E humanista por se tratar da estrutura individual do homem.

A lei é o liame natural que o homem deve realizar. A instrumentalização concreta da intenção de natureza que consinta o desenvolvimento humano deve ocorrer através da lei. Este é o ato generativo que deve ocorrer com fundamento ao critério epistêmico segundo a autopoiese do ôntico-humanista. Mas, para que isso ocorra, é necessário que os gestores do Direito aprendam e compreendam que a funcionalidade do Direito para a sociedade pode ser encontrada na intencionalidade de natureza do ôntico-humanista, que ocorre por meio da percepção sensória organísmica visando identificar as pulsões do Em Si ôntico.

O Direito possuirá fundamento de existência e conseguirá garantir a si mesmo se confirmar a capacidade de autorregulação e a autopoiese da ordem biológica humana. $\mathrm{O}$ Direito é bom se garante o desenvolvimento do ser humano, é mal se o faz regredir em sua evolução e enrobustece um sistema esquizofrênico de existência e aplicação no plano concreto.

Possui fundamento, é epistêmico, o Direito que consegue salvaguardar a autopoiese da racionalidade humana, que o constrói. O fundamento é o Em Si ôntico. É necessária a percepção orgânica para compreendê-lo em ato. O Direito é específico de ordem, que é o critério que informa saúde ou doença. A ordem segue a arquitetura anterior ao homem e que não foi criada pelo Direito. ${ }^{25}$

\footnotetext{
${ }^{24}$ Meneghetti (2012, p. 94) sobre o conceito de episteme: "Episteme é o conhecimento, a ciência fundada. Semente, raiz ou o que é próximo, íntimo ao princípio em si, ao princípio que faz ou dá presença ao real ou à evidência desse. Semente do conhecimento. Símbolo, signo que certifica o real, portanto, autoriza o processo lógico. Critério Primeiro para a lógica ou racionalidade estabelecida".

${ }^{25}$ Meneghetti (2010, p. 112) explica que: "Quando falamos de pessoas, falamos de almas, as quais são como o espírito intenciona. A alma é um momento onde o espírito é ação formal. Nós cientistas devemos ser
} 
A refundação do Direito possui respaldo na intencionalidade de natureza do ônticohumanista, verificada na evidência práxico-biológica do Em Si ôntico. O princípio memorare novíssima tua et perfectus eris (recorde os primeiros princípios e serás exato nas soluções) encontra-se no retorno ao ser através da leitura das informações emanadas pelo Em Si ôntico, processo de conhecimento que perpassa pela percepção orgânica do corpo.

A identificação e realização da pulsão do Em Si ôntico dependerá da equalização do Eu do ser humano. Conforme Meneghetti (2010, p. 256):

O Eu é princípio de realidade de toda autoconservação do organismo. A sua função é a defesa da distinção real na qual é colocado. Essa função prossegue no ser a mediação do universal para o individual. Esse medeia e controla o quanto existe em prol do organismo.

Quando falamos de Eu, entendemos a estrutura que tem a capacidade de mediar a realidade externa ao organismo. Enquanto o organismo parece andar em uma lei de expansão erótica, infantil, o Eu é aquela estrutura que nasce no momento em que o organismo seleciona o ambiente para si. Em âmbito psicológico, o Eu forma-se e põe-se junto ao que concretamente se dá. $O$ Eu nasce do processo de conscientização do próprio corpo, nasce processualmente no possuir do próprio corpo.

De acordo com Meneghetti (2010, p. 256), o Eu é formado por três instâncias, que são os chamados pressupostos psicobiológicos, a saber: a) Tecido orgânico ou código genético; b) Imediatismo de interação corpo-ambiente; e c) Incidência diretiva organizada do social. O tecido orgânico ou código genético é explicado pelo autor como resultado de três fatores: estado endócrino e emotivo dos dois adultos geradores; valor e intensidade de incidência emotiva e etérica durante a relação dos parceiros; e pelo processo do feto em ressonância ao estado emotivo e endócrino da mãe.

A segunda instância de formação do Eu (imediatismo de interação corpo-ambiente) é tratada pelo autor como a relação do organismo humano com o ambiente, sendo que a partir do momento em que esta interação é promovida, o organismo diferencia-se, sofre modificações. $\mathrm{O}$ ambiente faz realidade no ser humano.

Por fim, a terceira e última instância de formação do $\mathrm{Eu}$, a incidência diretiva organizada do social. Para Meneghetti (2010, p. 256), “o conjunto energético do organismo, que está se plasmando em um ambiente físico, é continuamente estimulado segundo os interesses do ambiente adulto, a sociedade". E mais, "o Eu é um precipitado do social ambiental; depois dessa fase determina-se a consciência. A consciência acontece 
mais por um processo social que orgânico".

Para o estudo proposto neste trabalho, interessa estabelecer a importância do Eu em relação ao meio externo e de que forma isso impacta e faz realidade no ser humano. A união dos seres humanos em sociedade provém de uma necessidade de segurança, abrigo e fortalecimento. Ao mesmo tempo da existência de benefícios, surgiram os contrapontos relacionados aos costumes e interações sociais, pois estas relações sociais, inevitavelmente, estimulam novas realidades no corpo e mente dos integrantes da comunidade.

Ao passo da formação da sociedade, todos os seres humanos acabaram envolvidos e impactados por novas realidades. Essa interação ocorre no sentido externo para o interno. Isto é, o campo informacional da sociedade envolve as pessoas que a compõe e nelas são introjetados os estereótipos predominantes naquela comunidade. Ocorre o percurso inverso de formação do Eu e, posteriormente, da consciência humana, pois a informação da vida, proveniente do Em Si ôntico, é interna ao ser humano e intimamente ligada ao ser humano, provém da interioridade do sujeito, o qual a projetará ao externo em fenomenologia.

Diante disso, o Eu, responsável por fazer, em boa parte da vida, fica sujeito aos estereótipos sociais. Inclusive decide conforme estes modelos comportamentais. Há de se concluir também que é impossível viver sem realizar ações acordadas com estereótipos, faz parte da convivência social. Contudo, cabe a cada pessoa o retorno às premissas da vida para redescobrir a sua essência de natureza e voltar a ter uma percepção holística do organismo, visando a recuperação e realização do projeto de vida.

Porquanto, é imprescindível conhecer e saber que o Eu, responsável pelo agir humano, é responsável pela intermediação da alma com o meio e que o meio vai impactar na percepção da alma. A questão é saber ler as informações do meio e projetar a alma para que absorva ou isole a informação a fim de que cause o menor, ou melhor, impacto possível no organismo do ser humano.

Todas as realizações do ser humano exato perpassam pela exatidão organísmica. A exatidão organísmica necessita que o sujeito retorne à premissa da existência humana, que é anterior a tudo. Cada célula do corpo carrega a essência da vida. Assim sendo, a vida está encarnada sob um aspecto biológico, que é o corpo e sua estrutura formada pelo tecido celular. A exatidão humana é indissociável da percepção organísmica, uma vez que o corpo humano é uma fenomenologia do próprio Em Si ôntico.

Meneghetti (2010, p. 113) ensina que a célula porta o núcleo, protoplasma e suas ramificações. Quando está em sua função biológica normal, constata os elementos 
químicos recolhidos pelo sangue e identifica-os. Por "identificar" o autor entende que a célula reconhece o outro como si, pois este é princípio da vida, aceitar aquilo que se identifica a mim como vivente. Isto é, a célula identifica o elemento trazido pelo sangue, o reconhece como seu e o absorve, faz metabolismo enriquecedor. Reversibilidade.

Para explicar o processo celular, o autor exemplifica com o caso do tumor, onde um mecanismo é obrigado a ser simbiotizado com a célula. A célula sofre o filtro de outro e introjeta somente aquilo que o filtro informa se igual. Assim, o elemento estranho à ordem natural entra e de forma progressiva a célula é destruída ou transformada, contra a natureza do ser. Com esse exemplo, a intenção do autor é explicar que a mente humana entende de duas formas, uma com o filtro e a outra sem. Quando existe o filtro (no caso o tumor), a verdade é aquela determinada pelo filtro. Prejudicial ao ser humano, mas, naquele momento, a verdade a ser seguida. O exemplo do tumor é uma contraposição a autopoiese.

Frente a isso, Meneghetti (2010) afirma que para levar a ciência ao ponto ontológico, é necessário eliminar os filtros da mente humana, pois o núcleo do protoplasma, o Em Si ôntico do organísmico existencial, contém o critério eterno. Para aqueles que buscam a compreensão da vida, é necessária a recuperação do critério eterno "que é ínsito na estrutura psicobiológia e fisiológica do nosso quântico existencial” (p. 114).

Assim o sendo, o corpo humano, livro da alma, carrega em cada célula o princípio elementar da existência individual, arquitetada pelo Ser. A chave de leitura das informações do Em Si ôntico é o corpo humano por completo. A estrutura corpórea funciona ao modo de um radar orgânico, em que cada emanação do Em Si ôntico provoca uma reação imediata no organismo. A análise e percepção da informação dependem da precisão orgânica em que o ser humano se encontra no momento.

A autopoiesis é o instituto que permite a autonomia organizativa orgânica do ser humano através da autoconstrução celular, mas sempre mantendo a essência do projeto de vida. Muitas células do corpo humano deixam de ser ativas e são substituídas por outras em virtude da autopoiese. Por isso, a estrutura orgânica mante-se viva e funcional, conservando a unidade de ação e a intencionalidade da vida.

É através desse raciocínio que ocorre a refundação do Direito no lastro da intencionalidade de natureza do ôntico-humanista, verificada na evidência práxicobiológica do Em Si ôntico. A precisão das ações concretas depende do acerto da chave de leitura das informações emanadas pela alma humana. Assim sendo, o princípio memorare 
novíssima tua et perfectus eris fenomeniza-se ao resgatar-se a intencionalidade de natureza que cada célula do corpo humano porta, eis que cada qual carrega o princípio de tudo, a arquitetura da vida.

\subsection{Aspectos práticos da Ontopsicologia aplicada ao Direito}

O encontro de si mesmo, o encontro com o projeto mensurado pela natureza, é a práxis fundamental para o sujeito que visiona realizar-se integralmente, de forma homologada ao seu centro de força vital. Ser concebido pelo mundo da vida significa ser projetado para realizar uma finalidade específica, individual, única e intransferível.

O projeto de vida de cada humano é de execução personalíssima. Não pode ser transferido, abnegado, permutado ou omitido. Simplesmente é. É de incumbência individual descobrir e projetar praticamente a virtualidade intrínseca ao ser. A depender da consciência de cada pessoa, da forma como a estrutura da personalidade formou-se ao longo da vida, a evidência de uma arquitetura anterior a própria existência encarnada nunca será colhida. Por outro lado, nem todas as pessoas compreendem que existe um propósito de existência que transcende o tradicional ciclo de nascer, crescer, reproduzir e morrer.

Trata-se de retomar o projeto de existência e responder de onde viemos, para que viemos e para onde vamos. A obtenção de respostas para estes três questionamentos remete o sujeito à integralidade do ser em existência histórica. Isto é, à homologação do Eu lógico-histórico $^{26}$ ao próprio projeto de vida. O ponto fundamental de toda compreensão existencial humana parte da tomada de consciência de que antes de tudo o humano deve saber colher a si mesmo, saber colher o seu projeto de existência, pois os sistemas sociais e as relações intersubjetivas transpassam pela realidade interna do ser humano. A compreensão exata da dimensão do que é o ser humano só é compreendida por quem compreende primeiramente a si mesmo.

Não há avanço, não há certeza, não há exatidão sem que o ser humano se autentique enquanto tal. Feito isso, uma nova dimensão de conhecimentos pode ser colhida. A

\footnotetext{
${ }^{26}$ Meneghetti (2010, p. 41) explica a relação entre o Eu lógico-histórico e o Em Si ôntico: “O Em Si ôntico é eterno, mas no espaço-tempo deste planeta quem tem as rédeas é o Eu lógico-histórico. O quântico é um dom da vida, ninguém nasce igual ao outro. O quanto depende do ser, mas a aplicação depende do Eu lógicohistórico. O Em Si ôntico tem o dom, mas é o Eu lógico-histórico que prepara o caminho [...]".

O Eu lógico-histórico é o poder da história que dá o nascimento ao Em Si ôntico. Se o Eu lógico-histórico não age com vontade momento a momento, não é possível a epifania. A escola, a sociedade, a Ontopsicologia, a OntoArte, são educações para um Eu lógico-histórico com capacidades e condutas vencedoras. Mas esta é uma escolha, não uma necessidade".
} 
essência é entender a si mesmo, compreender o ponto fulcral de existência para que depois se possa avançar com segurança e exatidão no jogo social. Da mesma forma, em relação ao labor jurídico. Existem as leis, os princípios, a jurisprudência, os costumes, mas quem interpreta e aplica o Direito à existência é o ser humano. Isto é, deve-se compreender o Direito, mas, sobretudo, o ser humano. A vida existiu de forma antecedente ao Direito. O Direito não criou a vida. A vida criou o Direito. E a vida pode ser compreendida através da Ontopsicologia.

Posto isso, preliminarmente, deve-se grafar que o intuito da terceira parte do presente trabalho é expressar a prática viva d ciência ontopsicológica na atividade jurídica. Para demonstrar a efetividade da conjugação da Ontopsicologia com o Direito, foram entrevistados quatro profissionais do Direito, com conhecimento e estudos da Ontopsicologia. A fim de preservar a identidade de cada qual se utilizará os elementos naturais Água, Terra, Fogo e Vento para representá-los e conferir ordem a justaposição dos resultados obtidos.

O critério de realização da entrevista foi a seleção de entrevistados com conhecimento da Ontopsicologia e que, dentro da atividade profissional, tornam-na instrumento de trabalho. As perguntas foram realizadas de forma idêntica a todos os entrevistados. A abordagem dos questionamentos foi iminentemente prática, sendo que o assunto central foi a aplicação da Ontopsciologia na prática do Direito e a instrumentalização do corpo humano para alcançar a percepção das informações provenientes da vida.

Utilizou-se a pesquisa qualitativa para a realização das entrevistas, com vista à abordagem fenomenológica. A partir das respostas proferidas pelos entrevistados houve a busca da compreensão da essência do discurso. A investigação do cotidiano jurídico através da narrativa de quatro profissionais, tendo como referencial a abordagem fenomenológica, revela a intenção do pesquisador em transpassar o plano teórico, conjugando-o à experiência humana.

Com a evolução das novas tecnologias, do surgimento de novos fatos sociais, antropológicos, bem como da globalização, este contexto exprime a necessidade de que os profissionais do Direito permaneçam em constante atualização e revisão de si mesmos. É fato incontroverso o surgimento de novas demandas no mercado de trabalho. Por isso, o operador do Direito deve otimizar todos os seus recursos naturais através da atuação 
profissional à luz do critério organísmico ${ }^{27}$. Essa é a passagem para a conexão com a vida e o encontro das soluções otimais para os casos específicos.

A primeira abordagem das entrevistas foi relacionada quanto a possibilidade ou não de ser aferido um refinamento técnico após a aplicação da Ontopsicologia na prática jurídica. A entrevistada Terra apresentou a seguinte resposta: Sim, é possível. Quando estamos conectados com a nossa alma, íntimo de si e no todo de si - quando estamos conosco em cada parte, nos tornamos mais inteligentes, acessamos o nosso intelecto de modo amplo e profundo, o que resulta em um trabalho mais preciso, de melhor desempenho.

Sobre o mesmo assunto, a entrevistada Água declarou que: É claro que é possível um refinamento técnico, porque: a) a RESPONSBILIDADE: você aprende que tudo depende de ti, a não culpar os outros. Se torna mais preciso e consciente com o seu trabalho e com os outros - clientes e colaboradores; b) Em Si ontico: ler o outro e as coisas de dentro adentro. Sem esse critério é tudo falso - tudo fora; c) Campo semântico: saber se está movendo ou se está sendo movido; d) Monitor de Deflexão: saber que existe esse mecanismo em todos e que distorce as coisas. O resumo que posso fazer é um só: ou é ou não é. Ou você está dentro e age de acordo com o Em Si ou está fora e é mais um na massa.

Para Fogo o conhecimento da Ontopsicologia, bem como sua aplicação do campo do Direito apresenta resultados positivos e vantajosos ao profissional, tais como: Economia de tempo e de estudo, facilidade em identificar a tese, dominar a intencionalidade faz com que os clientes venham mais facilmente, conhecer as resistências e os complexos ajuda a entender quando erramos, trabalhar com o judiciário, o que para muitos é penoso, se torna algo mais leve.

Nessa senda, VENTO respondeu ao questionamento com as seguintes palavras: Sem dúvida, um excepcional refinamento técnico, em sentido amplo. "Amplo” porque a operação jurídica não envolve somente a lei, mas também as pessoas, que, na verdade, são o fim último, a razão de ser das leis. Uma lei que não seja funcional às pessoas não deveria ser mantida em nosso sistema, ou ao menos não utilizada. A técnica ontopsicológica exige uma maestria, exige uma coerência entre aquilo que o sujeito

\footnotetext{
${ }^{27}$ Segundo Meneghetti $(2012$, p. 70) o critério organísmico é "Complexo de ações e reações determinadas pelo conjunto orgânico-corpóreo: em particular, o cérebro visceral, sistema cardíaco e pulmonar, o estômago e funções sexuais e eróticas. O critério organísmico é vetor de emocionalidade com ausência de interferências cerebrais, ideológicas. É a exclusão de qualquer imagem, síntese ou programa definido como memética".
} 
Saber Humano, ISSN 2446-6298, V. 9, n. 15, p. 12-43, jul./dez. 2019.

estuda, compreende, e nas ações cotidianas. Entretanto, para aplicar esse método é necessária uma "forma mentis" e também um estilo de vida. Esses dois aspectos de fundo depois informam o "modus operandi" do jurista: quem atender? Como atender? Que palavras usar? Qual tom de voz? Como dar aquela notícia, aquela opinião, aquele parecer, aquela resposta. A aplicação do método ontopsicológico durante todo o "arco" do atendimento ao cliente, portanto, confere uma sofisticação de toda a ação, de todo o exercício do operador jurídico. Seja por sua abrangência ou profundidade, o método ontopsicológico tem me consentido diversos melhoramentos, dos quais passo a destacar: 1) resultados: consigo antever a solução e depois implementá-la. Por exemplo: 1.1 uma acordo, qual melhor solução num determinado caso ou processo; 1.2) um enfrentamento até as últimas instâncias e com todas as "armas", seja para vencer ou mesmo para "ganhar tempo", para que depois o cliente possa se organizar para liquidar aquele débito, ou que vá até o final para buscar aquele Direito, sem ceder em nada, se for o caso. Tudo é relativo, ou seja, sem uma premissa absoluta. Depende daquela imagem inicial para a solução do problema. Assim, cada vez mais, meus processos tem dado os resultados previstos e também minhas orientações, nos casos de assessoria, tem sido cada vez mais assertivas; 2) resultados financeiros - maiores retornos e mais clientes para o escritório, que vem crescendo cada vez mais; 3) perfil dos clientes - com o refinamento, vai-se migrando para clientes com maior atuação, maior capacidade econômica e de ganho; 4) equipe aumentando e melhorando o perfil; e 5) qualidade do trabalho, em sentido geral, desde o atendimento, prazos, melhoria da estrutura de trabalho, etc.

É notório que os depoimentos demonstram o refinamento técnico e o melhoramento dos resultados profissionais daqueles que já conhecem a Ontopsicologia e aplicam-na em sua atuação, especialmente no que diz respeito a organização profissional, atuação e ganhos econômicos. Sobretudo, deve-se considerar que as respostas apontam o conhecimento ontopsicológico como a forma de desenvolver a leitura de uma determinada situação e, imediatamente, através da intuição ou da percepção organísmica, constata-se a evidência de uma solução otimal para o caso. A obtenção deste conhecimento ocorre através da consonância entre a estrutura orgânica da pessoa com o mundo da vida.

Adiante, é possível perceber que a Ontopsicologia também faz com que os profissionais compreendam o jogo do sistema social e consolidem uma forma mentis de atuação que lhes seja reforço à identidade. É consequencial que sobrevirão acertos e ganhos, sejam econômicos ou pessoais, os quais refletirão desde o atendimento do cliente 
até o resultado prático assertivo das orientações proferidas.

O ponto fulcral é acertar a ação conforme o Em Si ôntico. Posta a situação, a solução otimal transcorrerá a partir da exatidão do profissional com o seu projeto de vida. O Eu Lógico-histórico será o reflexo das pulsões do Em Si ôntico, que é a base de partida e local de chegada para ação jurídica perfeita, infalível.

A temática da resolução de conflitos e consultoria preventiva são assuntos extremamente atraentes, pois demandam preciosismo e a melhor qualidade de técnica dos profissionais, cujo maior objetivo é ser infalível. É sob essa premissa que surgiu o segundo questionamento das perguntas, relacionado a como ocorre a aplicação da Ontopsicologia na resolução dos conflitos jurídicos.

O entrevistado FOGO, por meio de sua experiência jurídica, respondeu a indagação enfocando a utilização da intuição: - A intuição é decisiva na resolução dos conflitos. Por mais que se domine a técnica, é a intuição (Em Si ôntico) que revela, a cada momento, que tese usar, em que ordem colocar as teses na petição, etc. Na audiência isto se revela ainda mais forte, pois no meio de tudo, mente do juiz, das partes, precisamos identificar o que falar, e de que jeito falar para que a vitória seja favorável ao cliente. No atendimento também, é preciso colher o que o cliente precisa ouvir para se sentir confiante.

Conforme a entrevistada Água a utilização da Ontopsicologia na resolução de conflitos jurídicos funciona da seguinte forma: - Primeira coisa que precisa ter num conflito jurídico é segurança e isso se dá se você tem o conhecimento geral e específico do processo e do Direito. Se tem o conhecimento, então você pode prever se vai ganhar ou perder a ação. A partir daí fica fácil negociar. Se vai perder faça um acordo. O acordo e a conciliação sempre são uma boa prática, o que muda são os valores do acordo com a probabilidade de ganhar ou perder. Relações Diplomáticas: com os outros advogados, com o juiz, com os peritos. Se tem isso a sua vida é facilitada. Seja amigável e simpático e não entre em brigas com os advogados ou juiz. Ter frieza e clareza - não se envolver com o problema do cliente. Terceiro ponto: ou você é ativo ou é passivo - lembre-se disso você escolhe. Quarto ponto: leia os sinais e use o campo semântico

Adiante, a entrevistada Terra ponderou que: - A Ontopsicologia é aplicada por mim, na resolução dos conflitos jurídicos, por meio da intuição, da percepção do caso concreto de modo amplo. O conhecimento técnico e profundo sobre as diversas situações que me deparo é essencial, mas é preciso compreender a totalidade do conflito, a sua origem, as pessoas envolvidas, o tempo histórico, a intenção das partes, os meus sonhos 
quando estou envolvida na sua resolução, as minhas reações, etc.

Sobre o assunto, Vento detalha sua experiência prática na aplicação da Ontopsicologia ao Direito: - A primeira coisa é que compreendo a aplicação desta ciência enquanto um método! Para que funcione, dê os resultados, a premissa é estar bem, estar “no ponto”, com a mente limpa e organismicamente disponivel ao problema (nesse caso jurídico) a ser enfrentado. Nessa condição, uma vez impactada a situação, surgem para mim as primeiras imagens: "fechar esse contrato", "aqui está ruim para meu cliente”, "lá estamos em vantagem". É mais comum, no dia-a-dia, a imagem dessa natureza, enquanto não temos tantas "fantasias", imagens aleatórias ou sonhos (com algumas exceções) dos casos que costumeiramente estou resolvendo. Uma vez auscultada essa imagem, que é um flash, normalmente muito rápido - talvez uma forma de intuição - faço confronto com o problema real e suas circunstâncias, iniciando assim um processo analítico de construção (histórica, técnica) da solução que já vislumbrei. Nessa fase, utilizo todas as minhas competências de leitura técnica do problema, leitura psicológica dos clientes, dos oponentes, dos "players", advogados, MP, Juízes etc. Utilizo a capacidade de síntese, comunicação, persuasão, enfim, todas as ferramentas, os instrumentos que me permitam chegar de modo mais econômico ao ponto máximo que pode ser um ganho, um acréscimo patrimonial ou de território de geração, ou mais simplesmente a minimização de uma perda, redução ou diluição no tempo do revés carmático já em ato sobre meu cliente. Durante o processo analítico já vou montando mentalmente a ação prática, ou seja, há também, há também um planejamento para aquele modo de resolver o problema cuja execução, depois, procuro implementar sempre com a mente ao ponto, pois tratando-se de questões complexas, considero fundamental cada detalhe, pois somente assim se assegura o máximo resultado e consegue se aproximar da excelência no servir, da perfeição (aqui entendida como a justa proporção, em sentido amplo, naquela circunstância).

Para alcançar a resolução dos conflitos jurídicos é de suma importância o conhecimento técnico do assunto que se está a tratar. Sobretudo, é necessário retomar o sentido da vida ao ser, que é infalível na prática. Esta retomada é fundamental para colher a conexão entre a existência e o projeto de vida, e assim descobrir que existe a intuição, que informa a solução otimal para cada situação vivida.

A percepção da vida ocorre quando direcionamos nossa existência em posição de encontro ao ser, ao projeto de natureza. Para que haja este encontro, é necessária a sanidade biológica. A intuição somente é colhida quando o sujeito é capaz de manter-se em 
sanidade, despindo-se dos estereótipos que não reforçam sua existência, e fortalecendo a caminhada ao encontro da alma. A partir do reforço às virtudes existenciais, as pessoas começam a executar a si mesmas enquanto idealização do Ser no plano concreto. A partir deste reforço, executam as fenomenologias do Em Si ôntico como reforço de existência.

A autorrealização possui como consequência imediata a assertividade nas orientações e tomadas de decisão no desenrolar dos trabalhos jurídicos. É a vida que opera em favor da evolução humana. É a arquitetura da vida aprimorando o Direito. A soma das ações realizadas em consonância do projeto de natureza resulta em ganho profissional e existencial. É matemática consequencial, se o profissional age conforme seu projeto de natureza, a orientação jurídica é perfeita dentro das possibilidades do caso. Colhe-se o otimal da vida para cada situação.

O autoconhecimento reforça a unidade de existência, sincroniza-a ao projeto de vida e faz realização do ser. A partir do conhecimento da causa do conflito, obtido por meio da intuição, ou da percepção organísmica, o profissional pode traçar uma estratégia mais eficaz para resolver a demanda. Conhecer a cadeia causal dos fatos que permeiam o processo é fundamental para exercer a profissão em cada decisão tomada nos trabalhos judiciais e extrajudiciais.

Salienta-se que a percepção é entendida de acordo Meneghetti (2010, p. 210) que a explica como a "atitude para receber ou captar a ação e mensurar-lhe o valor. Atitude para receber e reconhecer a informação concretamente ou em símbolo". A percepção organísmica é a percepção do orgânico racional em contato com relações intersubjetivas.

O conhecimento técnico do Direito permite ao profissional conhecer apenas metade do caso. O conhecimento da Ontopsicologia oportuniza ao sujeito o conhecimento completo sobre as causas que permeiam o problema. A partir disso, o profissional age conforme seu projeto de existência e colhe os frutos do autoconhecimento de forma gratificante e prazerosa.

Diante disso, o terceiro questionamento aos entrevistados ocorreu com o intento de explorar quanto a utilização da percepção organísmica durante uma consulta jurídica ou no trabalho a ser desempenhado. O intuito foi o de colher a forma mais prática de aplicação do critério organísmico no entendimento das causas e circunstâncias que permeiam e resolução de um conflito ou de assessoramento do cliente.

Posto o questionamento, a entrevistada Terra concluiu que: - Sim, considero imprescindivel utilizar o nosso corpo como referência para as nossas escolhas. Isto 
impacta diretamente no nosso trabalho e no que entregamos.

Para a mesma pergunta, a entrevistada Água reagiu com a seguinte resposta: - $O$ advogado é um intelectual e geralmente esquece do corpo. Assim é com quase todos. Então para quem sabe auscultar as variações organísmicas e lê-las é uma enorme vantagem, pois, como afirma o Prof. Meneghetti, a inteligência (ler a ação de dentro) é organísmica.

A percepção organísmica é fundamental para saber compreender a utilizar as informações semânticas que impactam reações nos órgãos do corpo humano. Para tanto, é necessária a sanidade biológica. Vale ressaltar que a sanidade não é simplesmente não ser acometido por alguma doença, é reconhecer a vida em sua proporção, é reconhecer o próprio Em Si ôntico e manter um estilo de vida adequado com o projeto de natureza. É fato que a grande maioria dos profissionais do Direito não utiliza a percepção orgânica no desenvolvimento do trabalho. Atualmente o labor técnico vincula-se a consulta das fontes do Direito.

Em uma percepção mais concreta, Fogo afirmou que: - utilizo muito a percepção organísmica. As vezes um cliente fala algo ou o juiz na audiência, e vem na hora uma azia, uma sensação de estômago inflado e pesado. Aí vejo que o caminho não é por ali. Às vezes, de outro lado, quando vem um comentário em atendimento ou em audiência, e me vem um impulso, do estomago ao esôfago, como quem diz: "fale isto".

Sob a mesma perspectiva Vento relatou: - Para mim, a percepção organísmica deve ser um exercício constante: e agora o que devo fazer? Qual a ação otimal para mim neste momento? Trabalhar? Comer? Descansar? Responder o questionário do Djovani? Trata-se de buscar sempre o melhor de si mesmo, para si mesmo, utilizando o próprio organismo não só como instrumento de ação, mas também como instrumento de conhecimento (cum essere), aferição da realidade (res), da minha verdade, naquele instante, naquela circunstância. Entretanto, verificar os detalhes do meu entorno, do (s) meu (s) interlocutor (es), que efeitos, sensação orgânica, que imagens me causam, que imagens me ocorrem, que reações provocam em meus órgãos, meu estado de ânimo etc., fazem parte sim e cada vez mais de meu dia-a-dia, e por conseguinte de meu exercício profissional cotidiano. Procuro aferir assim, em cada situação de atuação profissional, se a informação do que está se desenhando me causa ampliação, alegria, euforia, êxtase, disposição etc., é, portanto, positiva, ou se ao invés causa, rigidez, medo, náusea etc., ou seja, é negativa. 
Os relatos dos entrevistados são narrativas proferidas por profissionais que aplicam cotidianamente o cruzamento dos conhecimentos obtidos em Ontopsicologia e Direito. A partir deste entrelace, o resultado obtido indica uma verdadeira vantagem para enfrentar o jogo do Direito e o do sistema. A percepção do critério orgânico é uma forma de saber selecionar a escolha otimal para cada momento da atuação profissional.

Para o operador do Direito é difícil compreender a existência da possibilidade de conjugar o Direito com o conhecimento humano da Ontopsicologia. O convencional ensino acadêmico da ciência jurídica não apresenta esta possibilidade. Por isso, a busca pelo real da vida é uma opção até desacreditada para aqueles que já estruturaram a própria personalidade sem o reconhecimento da dimensão metafísica humana, que é passível de aplicação no Direito.

O nexo ontológico entre e a realidade cotidiana com o mundo da vida é a chave para consagrar a existência conforme o Em Si ôntico. A metabolização do Em Si ôntico é consentida mediante a assertividade das decisões praticadas. As decisões devem estar pautadas somente em um critério: o critério de natureza (procede-se por evidência). Compreende-se que o motivo pelo qual a Ontopsicologia está vinculada ao Direito natural ontológico, ou seja, ao Direito que possui a base natural originária do ser.

Percebe-se que a exatidão profissional é antecedida de uma base de conhecimento anterior, que é o conhecimento próprio, o conhecimento sobre o ser humano. A compreensão de que a vida é anterior ao Direito e de que o homem é a passagem de todas as aplicações racionais do Direito permite o acesso a compreensão da autopoiese do Direito. A exatidão ou não da ciência jurídica depende de quem a estuda e aplica no plano prático. Portanto, se a verdade do homem é ser igual ao projeto de natureza, o fundamento da ciência jurídica assenta-se no humanismo.

Consentir o humanismo no Direito significa aplicá-lo de acordo à ordem da vida. Justapô-lo nesta circunstância é realizar autopoiese. Significa conhecer, interpretar e aplicar o Direito conforme a ordem do cosmos, ou refunda-lo em base ao critério autopoiético do ôntico-humanista.

É crucial conhecer o que Meneghetti, ao tratar do critério autopoiético do ônticohumanista, refere como orgânico racional. O orgânico racional não é representado somente pela estrutura biológica do ser humano, é mais que isso. Trata-se da sanidade biológica, ou seja, funcionamento de todo corpo humano em seguimento das diretivas do Em Si ôntico. Por isso, Meneghetti refere que o orgânico racional é semelhante ao ser, é reversível em 
favor do ser, pois está no humano de acordo como a natureza estruturou biológica e geneticamente.

Parte da missão dos seres humanos é retomar o conhecimento sobre o próprio orgânico racional e utilizá-lo em progressão própria. O orgânico racional é autopoiético, pois autoproduz-se a todo o momento, como vida. $\mathrm{O}$ auto fazer-se significa renovação, o retorno ao centro vital, para a continuar a existir homologando a existência da pessoa ao seu ser.

Os profissionais do Direito podem compreender que o critério de refundação do Direito transpassa o próprio orgânico racional. Logo, a refundação do Direito ocorrerá por mentes hígidas que consigam compreender a real dimensão do ser na existência histórica e desse conhecimento entendam que o legado para a eternidade é autoproduzir-se em benefício próprio e, consequentemente, da sociedade.

Os depoimentos colhidos dos entrevistados ratificam a tese exposta. A união das ciências é praticada pelos profissionais que, antes de qualquer outro aspecto, privilegiam a exatidão própria, enquanto existência humana. Exatidão é agir conforme o Em Si ôntico. A ação do conforme só é possível através da compreensão do orgânico racional.

A essência dos relatos dos entrevistados demonstra que a partir da utilização do orgânico racional é possível acessar uma nova dimensão do conhecimento humano que permite a resolução dos conflitos jurídicos com maior precisão, considerando a busca pela causa dos fenômenos que culminaram na situação exposta pelo cliente. Outrossim, o orgânico racional é utilizado a todo momento à compreensão das variações e informações semânticas produzidas a partir da relação entre o cliente e o profissional do Direito. No atendimento, é preciso que o operador do Direito esteja auscultando o próprio organismo para compreender as reações produzidas pelas informações semânticas do cliente.

A utilização da teoria ontopsicológica na aplicação cotidiana do Direito reflete no modo de atender o cliente e de selecionar o perfil da carteira de clientes. O retorno à identidade de natureza consente no refinamento das habilidades de atendimento, do modo como portar-se, modo de como falar e entonar a voz. Para além, a retomada do Em Si ôntico permite a ratificação da vocação do profissional e, consequentemente, na seleção da clientela a ser atendida, bem como do melhoramento dos resultados profissionais.

Em suma, demonstra-se que a teoria ontopsicológica é confirmada na prática jurídica. Os depoimentos prestados ao presente estudo confirmam o objetivo da pesquisa, e mais, informam que a solução não só para o Direito, mas também para a sociedade está 
assentado no conhecimento do próprio humano.

\section{Considerações Finais}

Diante do trabalho exposto, é possível concluir que a Ontopsicologia possui finalidade prática de informar as diretivas para o sujeito fazer e começar a conhecer a si mesmo. A Ontopsicologia aplicada ao Direito é um diferencial no ensino e evolução do humano. Seguindo o método como é justaposta no plano concreto e acontece pelo Em Si ôntico dos seres humanos, revela-se como fator determinante para formar uma nova inteligência de profissionais do Direito.

O jurista é o mediador entre a lei e vida de seu cliente. A lei é fixa, mas o espírito da lei é dinâmico, variável. O jurista deve ajustar os recursos que a vida dispõe em relação aos instrumentos da lei. Tem-se um comportamento ambivalente: de um lado o cumprimento da lei, do outro, a necessidade de privilegiarem-se as necessidades da vida. $\mathrm{O}$ jurista deve utilizar o critério da vida como fundamento racional da construção de soluções para demandas jurídicas.

Portanto, o Direito é funcional ao ser humano quando garante a capacidade de autorregulação e a autopoiese da ordem biológica humana. O fundamento da evolução humana está garantido pelo Em Si ôntico. É deste princípio formal que partem as diretivas para que os juristas consintam a vida em ato histórico. Através do projeto de natureza que é possível garantir a autopoiese do Direito e, consequentemente, a refundação do Direito. Portanto, conclui-se que a refundação do Direito é embasada na intencionalidade de natureza do ôntico-humanista, consentida na evidência práxico-biológica do Em Si ôntico.

Por fim, restou constatado que é possível refundar o Direito com base no critério epistêmico segundo a autopoiese do ôntico-humanista, que é o vínculo de ligação entre o Direito e o mundo da vida. Para tanto, é necessário que os juristas tenham compreensão de que o Direito é muito maior que a leitura das leis, é também conhecimento da vida.

\section{Referências}

CASTAÑON, G. A. Construtivismo e ciências humanas. Disponível em: <http://www.cienciasecognicao.org/pdf/v05/m22542.pdf>. Acesso em: 12 dez. 2018. 
MATURANA, H. R. Emoções e linguagem na educação e na política. Tradução de José Fernando Campos Forte. Belo Horizonte: Ed. UFMG, 2002.

MATURANA, H. R. A ontologia da realidade. Organização e tradução Cristina Magro, Miriam Graciano e Nelson Vaz. Belo horizonte, MG: Ed. UFMG, 1997.

MENEGHETTI, Antonio. Cognição, ciência e vida cotidiana. Organização e tradução Cristina Magro e Victor Paredes. Belo Horizonte: Ed. UFMG, 2001.

MENEGHETTI, Antonio. Direito, Consiência e Sociedade. Recanto Maestro, RS:

Ontopsicológica Editrice, 2009.

MENEGHETTI, Antnio. O Critério Ético do Humano. Porto Alegre: Ontopsicologica Editrice, 2002.

MENEGHETTI, Antonio. Os jovens e a Ética Ôntica. Recanto Maestro: Ontopsicológica Editora Universitária, 2013.

MENEGHETTI, Antonio. Sistema e Personalidade. 3. ed. Recanto Maestro: Ontopsicológica Editrice, 2004.

MENEGHETTI, Antonio. Dicionário de Ontopsicologia. 2. ed. rev. atual. Recanto Maestro: Ontopsicológica Editora Universitária, 2012. 